\title{
SAN FRANCISCO 1955
}

As if from pages of a travelogue a little bit of Russia sparkles, birch trees and gypsies.

All day the meat simmers in its pot of blood resembling

borsch, while women,

bright scarves tied around their heads, pinch the edges of raised dough for pirogi, laughing at each other and making jokes. "Sin, sin, it is easier on your soul." And studiously the men part their beards to look like Grand Duke Nicholas.

Today the tourists from America will cross Geary Boulevard hiding their faces with cameras, with their insatiable appetites for authenticity. I stay out of sight in my room, crewcut, clean shaven, white bucks and levis, my face pressed against the window. Against the glass my nose flattens and my eyes slant. My skin yellows like isinglass. I remember my cousins along the Yenisey-the first crossed boundary, a river wider than the city that surrounds us. 